\title{
Involvement of Mcl1 in diallyl disulfide-induced G2/M cell cycle arrest in HL-60 cells
}

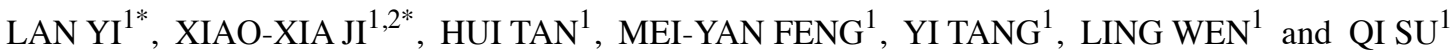 \\ ${ }^{1}$ Cancer Research Institute, University of South China, Hengyang 421001, Hunan Province; \\ ${ }^{2}$ Yun Cheng Central Hospital, YunCheng, Shanxi Province, P.R. China
}

Received November 17, 2011; Accepted January 12, 2012

DOI: 10.3892/or.2012.1704

\begin{abstract}
Diallyl disulfide (DADS) has shown potential as a therapeutic agent in various cancers. Previously, we found that myeloid cell leukemia sequence 1 ( Mcl1) was downregulated in DADS-induced cell cycle arrest in HL-60 human leukemia cells. Here, we investigated the role of this protein in DADS-induced G2/M cell cycle arrest in HL-60 cells. We demonstrated that DADS treatment significantly increased the proportion of $\mathrm{G} 2 / \mathrm{M}$ phase HL-60 cells $(\mathrm{P}<0.05)$ and caused a time-dependent significant downregulation of Mcll and the cell cycle-related proteins PCNA and CDK1 $(\mathrm{P}<0.05)$. Small interfering RNA-mediated knockdown of Mcl1 expression in HL-60 cells arrested the cell cycle in G2/M phase. By co-immunoprecipitation, we demonstrated that Mcl1 associated with PCNA and CDK1 in G2/M cell cycle arrest in DADS-treated HL-60 cells. DADS decreased the interaction of Mcl1 with PCNA and CDK1, leading to G2/M cell cycle arrest in HL-60 cells. Mcl1 plays an important role in DADSinduced G2/M cell cycle arrest in HL-60 human leukemia cells.
\end{abstract}

\section{Introduction}

The well-known characteristics of cancer cells are unlimited and uncontrolled cell proliferation $(1,2)$. Given that disruption of the cell cycle plays a crucial role in tumor progression (3), its modulation by phytochemicals seems to be a logical approach in controlling carcinogenesis. Thus, cell cycle regulation and modulation by various natural (plant-derived) and synthetic agents have gained widespread attention in recent years $(4,5)$.

Studies have suggested that the main active component of the cancer-fighting allyl sulfides in garlic is diallyl disulfide

Correspondence to: Professor Qi Su, Cancer Research Institute, University of South China, No. 28 Changshengxilu Road, Hengyang, Hunan 421001, P.R. China

E-mail: suqi1@hotmail.com

*Contributed equally

Key words: diallyl disulfide, G2/M arrest, HL-60 cells, Mcl-1
(DADS), which can induce cell cycle arrest in many tumor cells, including prostate cancer, lung cancer, and colon cancer (6-8). Previous studies in our laboratory confirmed that DADS was able to induce $\mathrm{G} 2 / \mathrm{M}$ phase cell cycle arrest in human gastric cancer cells and human colon cancer cells by activating the p38 MAP kinase signaling pathway $(9,10)$. We also used gene array technology to explore differentially expressed genes in DADS-induced cell cycle arrest in human leukemia HL-60 cells, and demonstrated downregulation of the myeloid cell leukemia sequence $1(M C L 1)$ gene, which is a member of the BCL2 family (11). Although the role of DADS as an antitumor agent has been established, its exact cytotoxic mechanism via cell cycle arrest is not completely clear.

MCL1 was originally identified as a gene upregulated in a human myeloblastic leukemia cell line induced to differentiate to monocyte lineage (12). Overexpression of this gene in cell lines caused decreased bromodeoxyuridine uptake and a slower doubling rate $(13,14)$. Knockout $\mathrm{Mcll}^{-/-}$mouse embryos failed to implant and therefore demonstrated peri-implantation lethality; however, perhaps most significantly, these embryos displayed no evidence of altered apoptosis. Conversely, overexpression of Mcl1 in transgenic mice enhanced hematopoietic cell growth and survival as well as promoting immortalization specifically in the myeloid lineage (15). Mcl1 is also required for $\mathrm{B}$ and $\mathrm{T}$ cell development and maintenance (16). In addition, Mcl1 modulates progression through the cell cycle $(13,17,18)$. The widespread expression of MCL1 in human tissues and its effects on apoptosis, differentiation, and the cell cycle confirm its crucial role in cellular homeostasis. Conversely, dysfunction of MCL1 regulation, expression, or degradation is observed in various diseases such as cardiopathy and cancer $(19,20)$. Mcl1 must serve other functions in addition to its activity as an anti-apoptotic $\mathrm{Bcl} 2$ family member. In one study, the antiproliferative function of MCL1 was clearly linked to its ability to bind proliferating cell nuclear antigen (PCNA), but was distinct from its anti-apoptotic activity (13). Another report identified a short form of MCL1 in the nucleus that bound and negatively regulated cyclin-dependent kinase 1 (Cdk1) activity, but its function in cell survival was unclear (14). Mcl1 plays a role in the ATR-dependent activation of Chk1, revealing a completely novel function of Mcl1 (21).

We hypothesized that Mcl1 is an important factor in DADS-induced G2/M cell cycle arrest in human leukemia HL-60 cells. This study showed that DADS decreases its 
association with PCNA and CDK1, leading to G2/M cell cycle arrest in HL-60 cells.

\section{Materials and methods}

Materials and reagents. DADS was purchased from Fluka Chemika Company. The total RNA extraction kit was purchased from Omega Bio-Tek, USA; the RT kit was purchased from Promega; anti-Mcl1 (MAB4602) antibodies were purchased from Abcam Biotechnology. The western blot detection kit, Seize ${ }^{\circledR}$ Classic Mammalian Immunoprecipitation kit, anti-PCNA (PC10), anti- $\beta$-actin (I-19), anti-CDK1 and anti-GAPDH antibodies, the small interfering RNA (siRNA) Transfection Reagent and Mcl1 siRNA (sc-35877) were purchased from Santa Cruz Biotechnology (Santa Cruz, CA).

Cell culture. Human acute myeloid leukemia HL-60 cells were imported by China Center for Type Cuture Collection (CCTCC, Wuhan, China), incubated in RPMI-1640 culture medium containing $10 \%$ calf serum in $37^{\circ} \mathrm{C}$, in saturated humidity and $5 \% \mathrm{CO}_{2}$. Cells were passaged into fresh medium every 2-3 days. Cells in logarithmic growth phase were used for the experiments. DADS was diluted to the indicated concentration in culture medium.

MTT. Cell viability was determined by the conventional 3-(4, 5-dimethylthiazol-2-yl)-2,5-diphenyl-tetrazolium bromide (MTT) reduction assay. MTT was performed in a routine manner as described (22). Results were expressed as percentage of MTT reduction: Cell inhibition rate $(\mathrm{IR} \%)=$ [A570 (control) - A570 (treatment)]/(A570 (control) x 100\%. A570 (control) is the absorbance of cancer cells without drug treatment; A570 (treatment) is the absorbance of cancer cells exposed to the drug.

Soft agar colony-forming experiments. Cell proliferation inhibition was evaluated by soft agar colony-forming experiments. Logarithmic growing-phase cells were collected, centrifuged and resuspended in culture medium; cell density was adjusted to $1.0 \times 10^{3} / \mathrm{ml}$. Different cell suspensions were rapidly mixed with agar, and the mixture immediately poured into 24 -well plates at $1 \mathrm{ml}$ each. The agar was allowed to solidify at room temperature. Then 24-well plates were then transferred into a $\mathrm{CO}_{2}$ incubator, at $37^{\circ} \mathrm{C}, 5 \% \mathrm{CO}_{2}$ and saturated humidity, and cultured 2-3 weeks. Colonies with diameters $>75 \mu \mathrm{m}$ were counted with the inverted microscope.

Flow cytometry. Flow cytometry was used to evaluate the cell cycle distribution of HL-60 cells after exposure to DADS. Untransfected and Mcll siRNA-transfected HL-60 cells were harvested after 24 or 48 -h treatment with 60 or $120 \mu \mathrm{M}$ DADS and centrifuged at $1,000 \mathrm{rpm}$ for $5 \mathrm{~min}$. Then, they were washed twice with phosphate-buffered saline (PBS), the cell concentration was adjusted to $1 \times 10^{6}$ cells $/ \mathrm{ml}$, and the cells were fixed with $70 \%$ ethanol. Before flow cytometry, the cells were washed twice with PBS and $15 \mu 1$ of $10 \mathrm{M}$ RNase A was added. The mixture was allowed to react for 3-5 min, gently mixed with $400 \mu \mathrm{l}$ of $50 \mathrm{mM}$ propidium iodide and incubated in the dark at $4^{\circ} \mathrm{C}$ for $30 \mathrm{~min}$. The distribution of cells at each stage of the cell cycle was measured by a flow cytometer.
Western blotting. The cells were lysed in lysis buffer $(10 \mathrm{mM}$ Tris-HCl pH 7.6, $100 \mathrm{mM} \mathrm{NaCl}, 1 \mathrm{mM}$ EDTA and $100 \mathrm{mg} / \mathrm{l}$ phenylmethylsulfonyl fluoride), then the cell debris was removed by centrifugation at $12,000 \mathrm{rpm}$ for $30 \mathrm{~min}$ at $4^{\circ} \mathrm{C}$. Protein concentrations were determined using a bicinchoninic acid protein quantification assay kit (Pierce, Rockford, IL), then $30 \mu \mathrm{g}$ protein per well was loaded onto $10 \%$ sodium dodecylsulfate (SDS)-polyacrylamide gels. After electrophoresis, protein bands were transferred electrophoretically to polyvinylidene fluoride membranes. The membranes were saturated and blocked with 5\% fat-free milk for $3 \mathrm{~h}$ at room temperature, then incubated with primary antibodies for $2 \mathrm{~h}$, with continuous rocking. After washing with PBS, the membranes were incubated with secondary antibodies (antimouse or anti-rabbit horseradish peroxidase-conjugated IgG). The membranes were then treated with an enhanced chemiluminescence reagent. Signals were detected by exposing the membranes to X-ray film; relative signal intensity was quantified with a Bio Image Intelligent Quantifier.

Mcll RNA interference (RNAi). Cells were harvested and their concentration adjusted to $1-2 \times 10^{6}$ cells $/ \mathrm{ml}$, and then were washed once with $2 \mathrm{ml}$ of siRNA Transfection Medium. Multiple doses of siRNA were tested: $6 \mu 1$ of $M c l l$ siRNA duplex and $6 \mu$ of siRNA Transfection Reagent was found to be optimal. Solutions A and B were made by diluting $6 \mu \mathrm{l}$ of Mcll siRNA duplex and $6 \mu$ of siRNA Transfection Reagent, respectively, into $100 \mu \mathrm{l}$ of siRNA Transfection Medium. Then Solution A was added to Solution B using a pipette, and was mixed gently by pipetting up and down before incubation for $30 \mathrm{~min}$ at room temperature. Then $0.8 \mathrm{ml}$ of siRNA Transfection Medium was added to each tube, mixed gently, and the solution was overlaid onto washed HL-60 cells. The cells were incubated for $5-7 \mathrm{~h}$ at $37^{\circ} \mathrm{C}$ in $5 \% \mathrm{CO}_{2}$, then $1 \mathrm{ml}$ of growth medium containing $10 \%$ serum was added without removing the transfection mixture. The cells were incubated for an additional 18-24 h, then the medium was aspirated and replaced with fresh normal growth medium. The cells were assayed and harvested for RT-PCR and western blotting 24-72 h later.

Co-immunoprecipitation. Typically, 2-4 mg of protein extract was used for immunoprecipitation. Extracted proteins are incubated for $2 \mathrm{~h}$ to overnight with either $2 \mu \mathrm{g}$ of anti-Mcl1 or $1 \mu \mathrm{g}$ of anti-PCNA antibody. The antibody-bound proteins were precipitated with Protein G-agarose beads. The protein complexes were eluted in SDS sample buffer.

Statistical analysis. The data were analyzed using SPSS v.12.0 statistical software (SPSS, Inc., Chicago, IL). Data were presented as mean $\pm \mathrm{SD}$. Differences between the experimental and control groups were detected by $t$-test; $\mathrm{P}<0.05$ was considered statistically significant.

\section{Results}

DADS inhibited HL-60 cells viability in a dose- and timedependent manner. As shown in Fig. 1A and B, we investigated the effect of DADS on cell viability. A concentration- and time-dependent loss in cell viability was observed in HL-60 

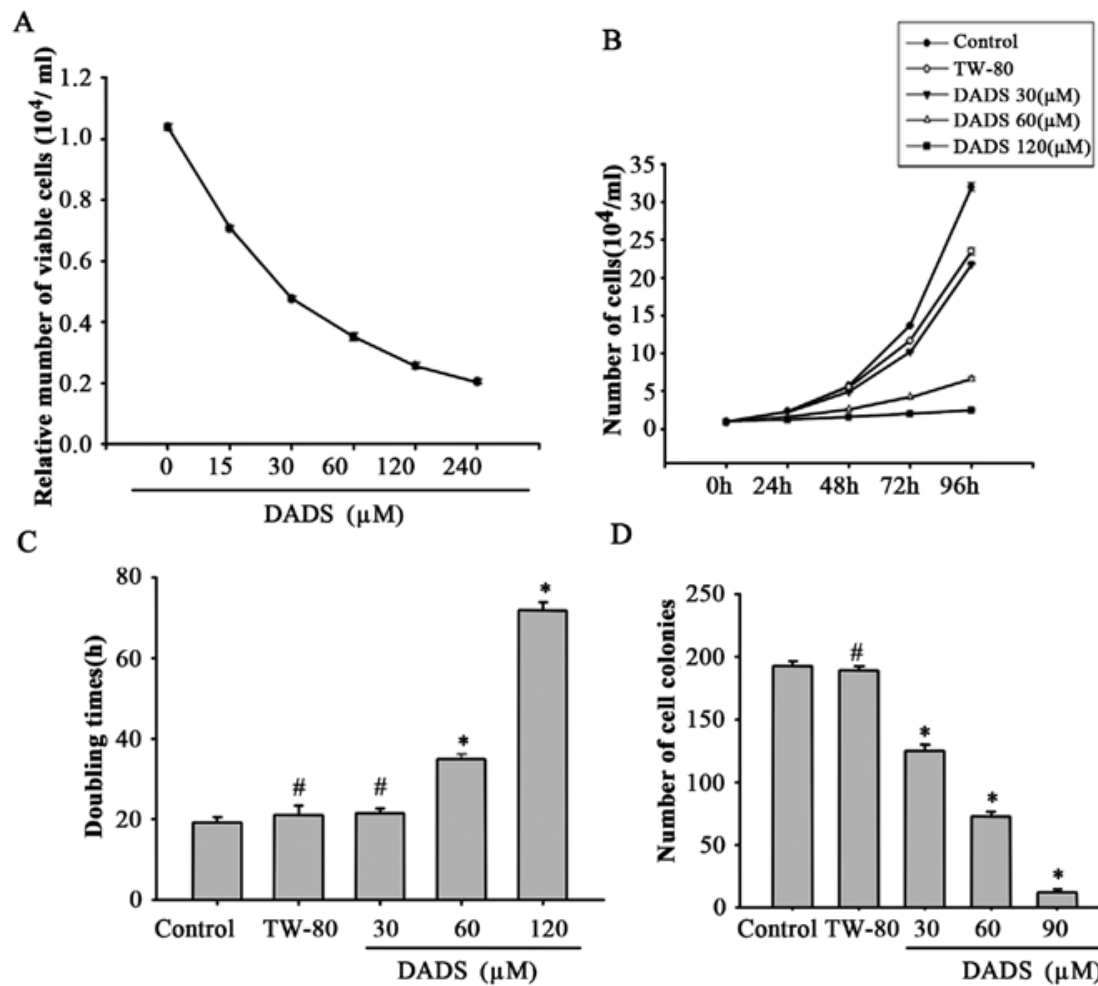

D

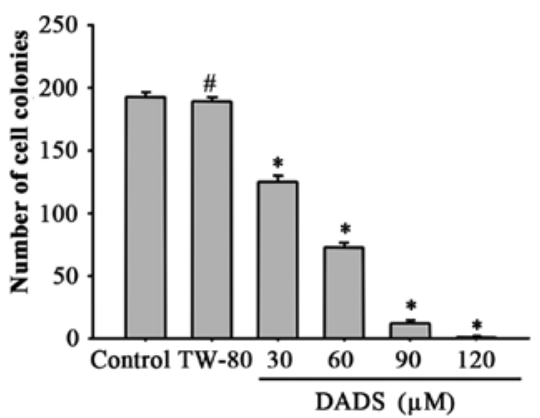

Figure 1. DADS inhibits HL-60 cell viability in a dose- and time-dependent manner. (A) The inhibiting curve of proliferation in HL-60 cells treated with different concentration DADS for $48 \mathrm{~h}$ (mean $\pm \mathrm{SD}, \mathrm{n}=6$ ). (B) Cell growth curve of HL-60 cells treated with different concentration of DADS for different times. (C) The population doubling time of HL-60 cells (mean $\pm \mathrm{SD}, \mathrm{n}=3$ ). ${ }^{*} \mathrm{P}>0.05$ vs. control while ${ }^{*} \mathrm{P}<0.05$ vs. control. (D) The inhibition rates of the effect of different concentrations of the DADS on colony formation of HL- 60 cells (mean $\pm \mathrm{SD}, \mathrm{n}=3$ ). ${ }^{\#} \mathrm{P}>0.05$ vs. control while ${ }^{*} \mathrm{P}<0.05$ vs. control.
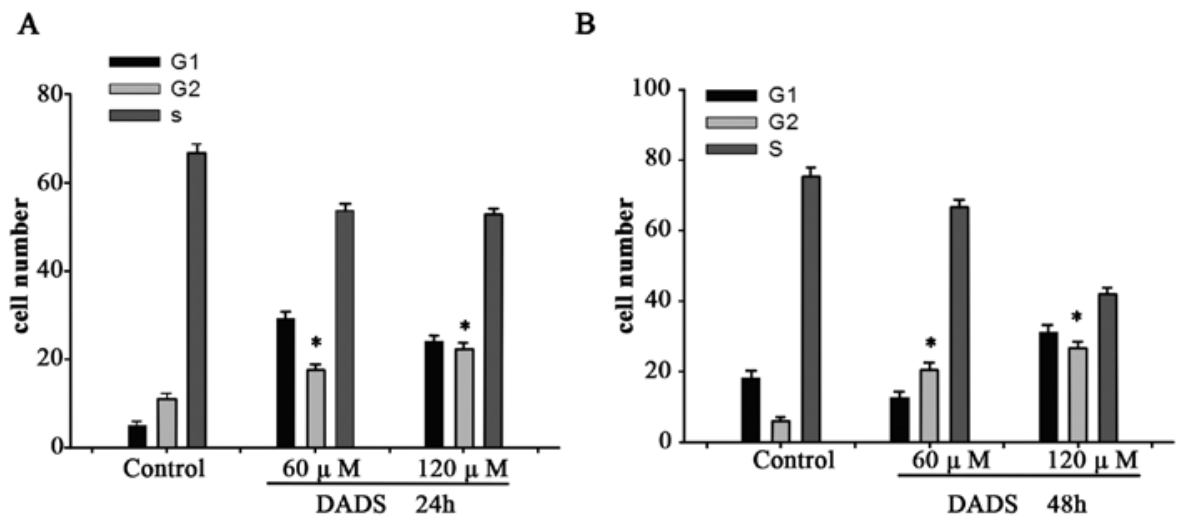

Figure 2. Flow cytometry analysis of cell cycle distribution in HL-60 cells. The data represent the mean $\pm \mathrm{SD}$ of three independent experiments. " $\mathrm{P}<0.05$ vs. control group (by t-test). (A and B) Cell cycle distribution of HL-60 cells treated with 60 or $120 \mu \mathrm{M}$ DADS for $24 \mathrm{~h}$ (A) or $48 \mathrm{~h}$ (B).

cells exposed to varying concentrations of DADS $(15 \mathrm{mM}, 30$, $60,120$ and $240 \mu \mathrm{M})$ for different time intervals $(12,24,48,72$ and $96 \mathrm{~h}$ ). As shown in Fig. 1C, the population doubling time of untreated HL-60 cells was $19.14 \mathrm{~h}$, the population doubling time of Tween-80 and $30 \mu \mathrm{M}$ DADS group did not change much $(\mathrm{P}>0.05)$, while at concentration of $120 \mu \mathrm{M}$ DADS, the population doubling time was $71.82 \mathrm{~h}(\mathrm{P}<0.05)$. Under the inverted microscope, we found colony formation in soft agar decreased when the concentrations of DADS increased (Fig. 1D). HL-60 cells exposed to 30, 60, 90 and $120 \mu \mathrm{M}$ DADS, the inhibition rates were $35.06,62.10,93.79,99.35 \%$, respectively, indicating that DADS significantly inhibited the proliferation of the HL-60 cells in a dose-dependent manner $(\mathrm{P}<0.05)$, and Tween-80 can not significantly inhibit colony formation of HL-60 cells $(\mathrm{P}>0.05)$. Overall, DADS was strong anti-proliferative to HL-60 cells.

Effect of DADS on the cell cycle distribution of HL-60 cells. By flow cytometry, the proportion of $\mathrm{G} 2 / \mathrm{M}$ phase cells was 17.6 and $22.3 \%$ after HL-60 cells were treated for $24 \mathrm{~h}$ with 60 and $120 \mu \mathrm{M}$ DADS, respectively (Fig. 2A). After $48 \mathrm{~h}$ treatment with 60 and $120 \mu \mathrm{M}$ DADS, the proportion of G2/M phase cells was 20.6 and 26.7\%, respectively (Fig. 2B). Compared with the control group, the proportion of G2/M 
A

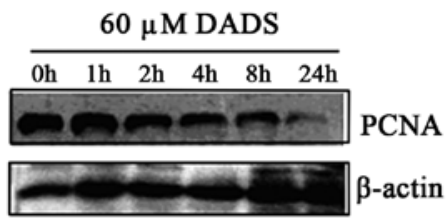

C

$\mathrm{E}$

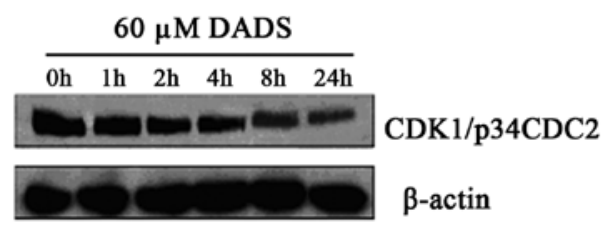

B

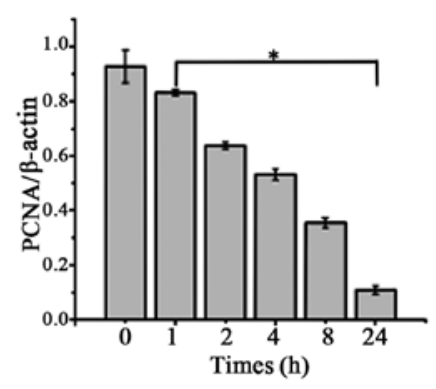

D

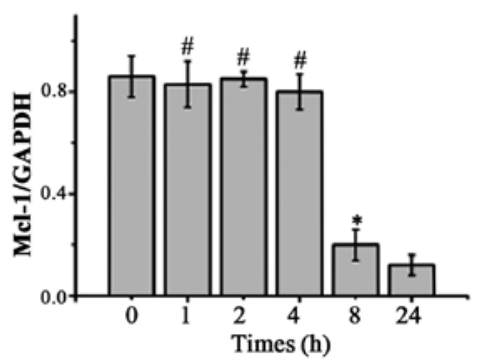

F

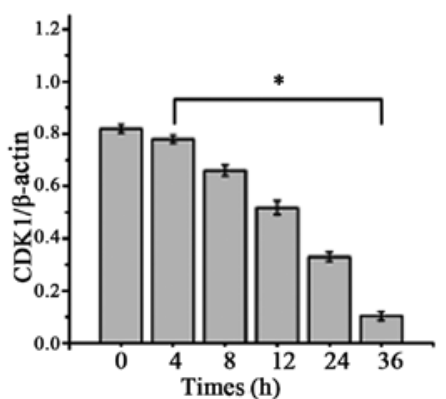

Figure 3. Western blot analysis of the expression of PCNA, Mcl1, and CDK1/p34CDC2 in HL-60 cells after treatment with $60 \mu \mathrm{M}$ DADS. (A) PCNA levels decreased in a time-dependent manner relative to $\beta$-actin when HL-60 cells were treated with $60 \mu \mathrm{M}$ DADS. (B) Quantitation of the data in (A). The values are the means \pm SD of three independent experiments. ${ }^{*} \mathrm{P}<0.05$ vs. $0 \mathrm{~h}$ group (by t-test). (C) Mcl1 levels decreased in a time-dependent manner relative to GAPDH when HL-60 cells were treated with $60 \mu \mathrm{M}$ DADS. (D) Quantitation of the data in (C). The values are the means \pm SD of three independent experiments. ${ }^{*} \mathrm{P}<0.05$ vs. 0 h group; ${ }^{*} \mathrm{P}>0.05$ vs. 0 h group (by t-test). (E) CDK1/p34CDC2 levels decreased in a time-dependent manner relative to $\beta$-actin when HL-60 cells were treated with $60 \mu \mathrm{M}$ DADS. (F) Quantitation of the data in (E). The values are the means $\pm \mathrm{SD}$ of three independent experiments. ${ }^{*} \mathrm{P}<0.05 \mathrm{vs} .0 \mathrm{~h}$ group (by t-test).

phase cells increased dramatically after DADS treatment at both time-points and for both concentrations $(\mathrm{P}<0.05)$.

Effect of DADS on the expression of PCNA, Mcll and CDK1 in HL-60 cells. By western blotting, we found that the levels of PCNA were significantly decreased in a time-dependent manner when HL-60 cells were exposed to $60 \mu \mathrm{M}$ DADS for 1-24 h $(\mathrm{P}<0.05$; Fig. 3A and B). The levels of Mcl1 had not changed by $4 \mathrm{~h}$, but dramatically decreased by $8 \mathrm{~h}$, and maintained a low level over rest of the $24 \mathrm{~h}(\mathrm{P}<0.05$; Fig. $3 \mathrm{C}$ and D). The expression of CDK1/p34CDC2 was downregulated after HL-60 cells were treated with $60 \mu \mathrm{M}$ DADS for 4-24 h $(\mathrm{P}<0.05$; Fig. 3E and $\mathrm{F})$. These data suggest that DADS affects the expression of cell cycle-related proteins in HL-60 cells.

Effect of Mcll RNAi on cell cycle distribution in DADS-treated $H L-60$ cells. Next, we inhibited $M c l l$ expression in HL-60 cells using RNAi. Western blotting clearly showed a knockdown effect; the inhibition rate was $\sim 85.3 \%$. The control, PBS, did not affect the expression of Mcl1 (Fig. 4A and B). As shown in
Fig. 4C and D, after treatment with $60 \mu \mathrm{M}$ DADS for $48 \mathrm{~h}$, the percentage of cells in $\mathrm{G} 2$ phase increased from 16.4 to $28.2 \%$ $(\mathrm{P}<0.05)$. In Mcll siRNA-treated cells, the percentage of G2 phase cells also increased to $19.4 \%(\mathrm{P}<0.05)$. The greatest increase, to $34.2 \%$, was observed in $M c l 1$ siRNA- and $60 \mu \mathrm{M}$ DADS-treated cells $(\mathrm{P}<0.05)$. These results demonstrate that pretreatment of HL-60 cells with $M c l l$ siRNA arrests the cell cycle in $\mathrm{G} 2 / \mathrm{M}$ phase.

Mcll associates with PCNA and CDK1 in G2/M cell cycle arrest in DADS-treated HL-60 cells. Next, we used co-immunoprecipitation to investigate whether PCNA and/or CDK1 co-immunoprecipitated with Mcl1 in DADS-treated HL-60 cells. As shown in Fig. 5, PCNA co-immunoprecipitated with Mcl1 in untreated HL-60 cells, and this association decreased substantially in DADS-treated cells. Similarly, CDK1 co-immunoprecipitated with Mcl1 in untreated HL-60 cells and the association decreased substantially in DADS-treated cells. These data suggest that Mcl1 decreases its association with PCNA and CDK1 in G2/M phase arrest in DADS-treated cells. 
A

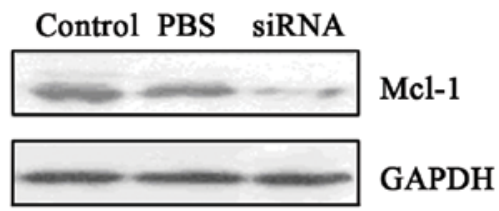

C
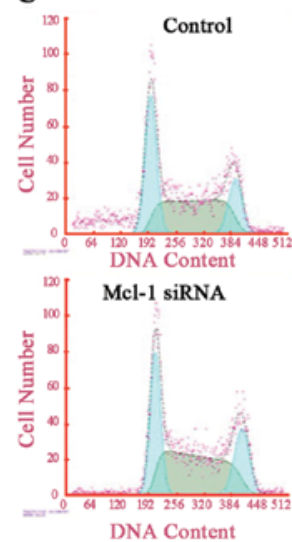
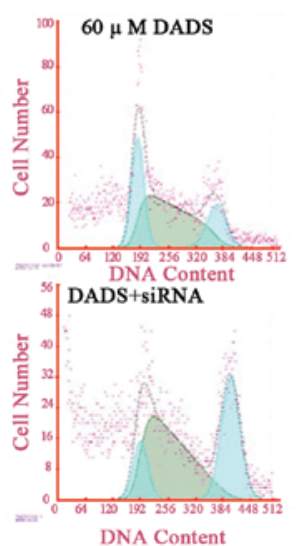

B

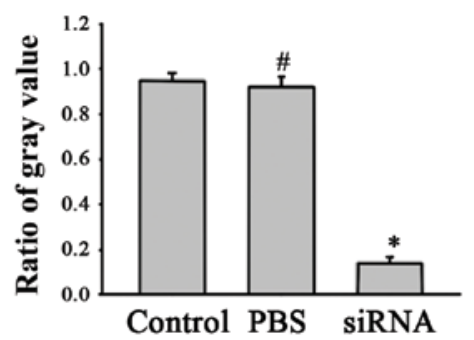

$\mathrm{D}$

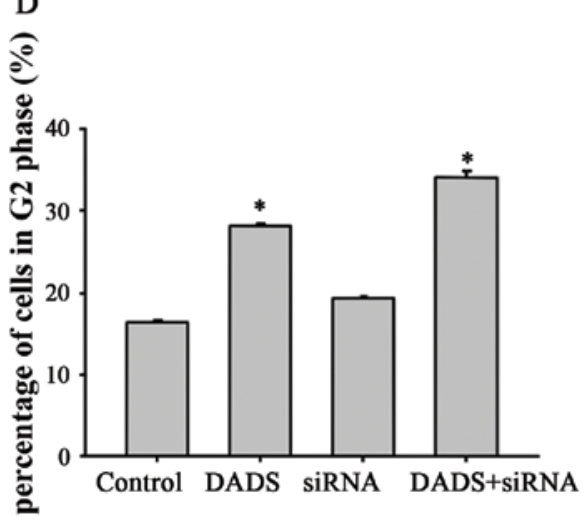

Figure 4. Effect of Mcll RNAi on cell cycle distribution in DADS-treated HL-60 cells. (A) Western blot indicating specific inhibition of Mcl1 expression by RNAi in HL-60 cells. PBS, phosphate-buffered saline control. (B) Quantitation of the data in (A). The values represent the mean \pm SD of three independent experiments, with each experiment comprising duplicate samples. " $\mathrm{P}<0.05$ vs. control; " $\mathrm{P}>0.05$ vs. control (by t-test). (C) By flow cytometry, treatment of HL-60 cells with DADS or with $M c l 1$ siRNA increased the proportion of cells in G2/M phase. Treating the cells with both DADS and $M c l 1$ siRNA increased the proportion still further. (D) Quantitation of the data in (C). The data represent the means \pm SD of three independent experiments. ${ }^{*} \mathrm{P}<0.05 \mathrm{vs}$. control cells (by t-test).

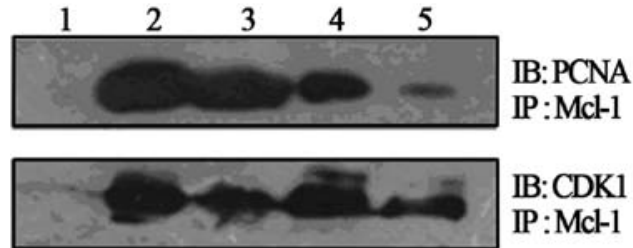

Figure 5. Co-immunoprecipitation of PCNA and CDK1 with Mcl1. HL-60 cell extract or anti-Mcl1-immunoprecipitated protein (IP) from HL-60 cells was immunoblotted (IB) with anti-PCNA and anti-CDK1 antibodies. 1, IgG; 2, control HL-60 cell extract; 3, extract from HL-60 cells treated with $60 \mu \mathrm{M}$ DADS for $4 \mathrm{~h} ; 4$, anti-Mcll-immunoprecipitated protein from control cells; 5 , anti-Mcl1-immunoprecipitated protein from DADS-treated cells.

\section{Discussion}

The main active component of the cancer-fighting allyl sulphides in garlic is apparently diallyl disulphide (DADS), which has been reported to induce cell apoptosis and cycle arrest in many types of tumour cells (23). Previous studies in our laboratory confirmed that DADS induced the cell cycle arrest of human gastric cancer cells and human colon cancer cells by activating the p38 MAP kinase signaling pathway $(9,10)$. The mechanisms underlying the induction of cell cycle arrest by DADS are not completely clear. The results of gene array technology dedicated that downregulation of the myeloid cell leukemia sequence 1 (MCL1) gene in DADS-induced cell cycle arrest HL-60 cells (11). This indicates that MCL1 is involved in DADS-related induction of cell cycle arrest in HL-60 cells.
We previously reported that low doses $(7.5 \mu \mathrm{M})$ of DADS have significant anti-proliferative effects, and can induce differentiation in leukemia HL-60 cells (24). The present study used moderate doses (15-120 $\mu \mathrm{M})$ of DADS to induce cell cycle arrest in HL-60 cells. Based on the preliminary work, this study further shows that the growth of HL-60 cells is inhibited when they are exposed to DADS. The results of MTT assays and soft agar colony-forming experiments showed that DADS inhibits the viability and proliferation of the HL-60 cells in a dose-dependent manner. This result indicates that DADS inhibited HL-60 cells viability in a dose- and timedependent manner.

The Mcl1 gene, located on chromosome 1q21, was first identified as an early gene induced by 12-O-tetradecanoylphorbol 13-acetate (TPA) exposure in the human myeloblastic leukemia cell line ML-1 (12). Another study revealed that Mcll played an important role in apoptosis (25-28). The findings of Yoon et al provided insight into a new regulatory circuit that controls cell death and survival by the coordinated actions of Mcl1 (29). Target Mcl1 may be effective for the treatment of melanoma in combination with agents that disrupt fibronectinintegrin signaling (30). Like other Bcl2 family members, Mcl1 is an oncogene that promotes tumorigenesis, protects therapeutic target in multiple types of cancer (31).

In a previous study, we revealed that DADS can induce G2/M phase arrest in HL-60 cells. In this study, we found that the expression of Mcl1, PCNA, and CDK1 decreased in G2/M phase arrest of HL-60 cells induced by DADS. Using flow cytometry, we found that HL-60 cell cycle progression 
was delayed after siRNA-mediated silencing of the Mcl1 gene, suggesting that $M c l l$ is involved in $\mathrm{G} 2 / \mathrm{M}$ arrest. The percentage of G2/M cells was increased in the siRNA- and DADS-treated cells compared with that in wild-type cells treated with DADS. This showed that $\mathrm{Mcll}$ gene silencing enhances the effect of DADS-induced G2/M arrest in HL-60 cells.

The ability of Mcll to inhibit cell cycle progression has been reported previously, and was attributed to an effect on $\mathrm{S}$ phase, based on the decreased ability of Mcl1-expressing cells to incorporate bromodeoxyuridine (13). These authors showed that Mcl1 physically and functionally interacts with PCNA. The Mcl1-PCNA interaction is unique because PCNA interacts only with Mcl1 and not with the other Bcl2 family members. The functional significance of the Mcl1-PCNA interaction may be that Mcl1 interferes with cell cycle progression through its binding to PCNA. Our current data support the notion that Mcl1 is a regulatory molecule that interfaces between apoptosis and cell cycle progression. PCNA belongs to the family of DNA sliding clamps ( $\beta$ clamps), which are structurally and functionally conserved, despite barely any sequence similarity. PCNA plays a critical role in DNA replication. PCNA is loaded onto DNA by the conserved chaperone-like complex RFC (32). The RFC-PCNA complex then binds to the RNA priming site, allowing DNA polymerase to bind PCNA and initiate DNA replication (33). In this study, PCNA co-immunoprecipitated with Mcl1 in untreated HL-60 cells, but this association decreased substantially in DADS-treated cells. The same was found for CDK1. These data suggest that Mcll decreases its association with PCNA or CDK1 to mediate $\mathrm{G} 2 / \mathrm{M}$ phase arrest in DADS-treated cells.

In conclusion, our study clearly shows, first, that DADS not only restrains the HL-60 cell viability and proliferation, but also can induce G2/M phase arrest in HL-60 cells; second, Mcl1 is an important factor in DADS-induced G2/M cell cycle arrest in human leukemia HL-60 cells; and third, DADS decreases Mcl1 association with PCNA and CDK1, leading to G2/M phase cell cycle arrest in human leukemia HL-60 cells. However, the exact mechanisms of the induction of tumor cell cycle arrest by DADS need further investigation.

\section{Acknowledgements}

This project was sponsored by the Hunan Provincial Natural Science Foundation of China (no. 07JJ6155), the Graduate Innovative Project of Hunan Province of China Department Education (2009CXJJ7), the National Natural Scientific Founation of China (81100375), the Patency Foundation of Innovation Platform of Human Provincial University of China (11K057), the PhD Initial Funding of University of South China (2011XQD60), and the Foundation of the Construct Program of the Key Discipline in Hunan Province of China (no. 2006-180).

\section{References}

1. López-Sáez JF, de la Torre C,Pincheira J and Giménez-Martín G: Cell proliferation and cancer. Histol Histopathol 13: 1197-1214, 1998.

2. Rew Da and Wilson GD: Cell production rates in human tissues and tumours and their significance. Eur J Surg Oncol 26: 405-417, 2000 .
3. Michelle D: Cell cycle control and cancer. Curr Sci 81: 515-522, 2001.

4. Lin JK: Cancer chemoprevention by tea polyphenols through modulating signal transduction pathways. Arch Pharm Res 25: 561-571, 2002 .

5. Sun J, Chu YF, Wu X and Liu RH: Antioxidant and antiproliferative activities of common fruits. J Agric Food Chem 50: 7449-7454, 2002

6. Wu XJ, Kassie F and Mersch-Sundermann V: The role of reactive oxygen species (ROS) production on diallyl disulfide (DADS) induced apoptosis and cell cycle arrest in human A549 lung carcinoma cells. Mutat Res 579: 115-124, 2005.

7. Arunkumar A, Vijayababu MR, Srinivasan N, Aruldhas MM and Arunakaran J: Garlic compound, diallyl disulfide induces cell cycle arrest in prostate cancer cell line PC-3. Mol Cell Biochem 288: 107-113, 2006.

8. Song JD, Lee SK, Kim KM, et al : Molecular mechanism of diallyl disulfide in cell cycle arrest and apoptosis in HCT-116 colon cancer cells. J Biochem Mol Toxicol 23: 71-79, 2009.

9. Yuan JP, Wang GH, Ling H, et al: Diallyl disulfide-induced G2/M arrest of human gastric cancer MGC803 cells involves activation of p38 MAP kinase pathways. World J Gastroenterol 10: 2731-2734, 2004.

10. Liao QJ, Su J, He J, Song Y, Tang HL and Su Q: Effect of diallyl disulfide on cell cycle arrest of human colon cancer SW480 cells. Ai Zheng 28: 138-141, 2009 (In Chinese).

11. Lin M, Xie HL, Su Q, et al : Effects of diallyl disulfide on differential expression of apoptosis-associated genes in leukemia cell line HL-60. Ai Zheng 26: 351-356, 2007 (In Chinese).

12. Kozopas KM, Yang T, Buchan HL, Zhou P and Craig RW: MCL1, a gene expressed in programmed myeloid cell differentiation, has sequence similarity to BCL2. Proc Natl Acad Sci USA 90: 3516-3520, 1993.

13. Fujise K, Zhang D, Liu J and Yeh ET: Regulation of apoptosis and cell cycle progression by MCL1. Differential role of proliferating cell nuclear antigen. J Biol Chem 275: 39458-39465, 2000.

14. Jamil S, Sobouti R, Hojabrpour P, Raj M, Kast J and Duronio V: A proteolytic fragment of Mcl-1 exhibits nuclear localization and regulates cell growth by interaction with $\mathrm{Cdk} 1$. Biochem J 387: 659-667, 2005.

15. Rinkenberger JL, Horning S, Klocke B, Roth K and Korsmeyer SJ: Mcl-1 deficiency results in peri-implantation embryonic lethality. Genes Dev 14: 23-27, 2000.

16. Opferman JT, Letai A, Beard C, Sorcinelli MD, Ong CC and Korsmeyer SJ: Development andmaintenance of B and T lymphocytes requires antiapoptotic MCL-1. Nature 426: 671-676, 2003.

17. Zhou P, Qian L, Bieszczad CK, Noelle R, Binder M, Levy NB and Craig RW: Mcl-1 in transgenic mice promotes survival in a spectrum of hematopoietic cell types and immortalization in the myeloid lineage. Blood 92: 3226-3239, 1998.

18. Le GS, Podar K, Amiot M, et al: VEGF induces Mcl-1 up-regulation and protects multiple myeloma cells against apoptosis. Blood 104: 2886-2892, 2004

19. Krajewski S, Bodrug S, Krajewska M, Shabaik A, Gascoyne R, Berean K and Reed JC: Immunohistochemical analysis of Mcl-1 protein in human tissues. Am J Pathol 146: 1309-1319, 1995.

20. Craig RW: MCL1 provides a window on the role of the BCL2 family in cell proliferation, differentiation and tumorigenesis. Leukemia 16: 444-454, 2002.

21. Jamil S, Mojtabavi S, Hojabrpour P, Cheah S and Duronio V: An essential role for MCL-1 in ATR-mediated CHK1 phosphorylation. Mol Biol Cell 19: 3212-3220, 2008.

22. Qin L,Zhang X,Zhang L, et al: Downregulation of BMI-1 enhances 5-fluorouracil-induced apoptosis in nasopharyngeal carcinoma cells. Biochem Biophys Res Commun 371: 531-535, 2008.

23. Wu X, Kassie F and Mersch-Sundermann V: Induction of apoptosis in tumor cells by naturally occurring sulfur-containing compounds. Mutat Res 589: 81-102, 2005.

24. Wu MH, Tang L, Li LP, Huang WG and Su Q: Effect of growth inhibition and differentiation of HL-60 cell induced by diallyl disulfide. Zhonghua Xue Ye Xue Za Zhi 25: 300-302, 2004.

25. Okumura K, Huang $S$ and Sinicrope FA: Induction of Noxa sensitizes human colorectal cancer cells expressing Mcl-1 to the small-molecule Bcl-2/Bcl-xL inhibitor, ABT-737. Clin Cancer Res 14: 8132-8142, 2008.

26. Kucharzewska P, Welch JE, Svensson KJ and Belting M: The polyamines regulate endothelial cell survival during hypoxic stress through PI3K/AKT and MCL-1. Biochem Biophys Res Commun 380: 413-418, 2009. 
27. Gobessi S, Laurenti L, Longo PG, et al: Inhibition of constitutive and BCR-induced Syk activation downregulates Mcl-1 and induces apoptosis in chronic lymphocytic leukemia B cells. Leukemia 23: 686-697, 2009.

28. Mallick S, Patil R, Gyanchandani R, et al: Human oral cancers have altered expression of Bcl-2 family members and increased expression of the anti-apoptotic splice variant of Mcl-1. J Pathol 217: 398-407, 2009

29. Yoon S, Ha HJ, Kim YH, et al: IEX-1-induced cell death requires BIM and is modulated by MCL-1. Biochem Biophys Res Commun 382: 400-404, 2009.

30. Boisvert-Adamo K, Longmate W, Abel EV and Aplin AE: Mcl-1 is required for melanoma cell resistance to anoikis. Mol Cancer Res 7: 549-556, 2009.
31. Akgul C: Mcl-1 is a potential therapeutic target in multiple types of cancer. Cell Mol Life Sci 66: 1326-1336, 2009.

32. Majka $J$ and Burgers PM: The PCNA-RFC families of DNA clamps and clamp loaders. Prog Nucleic Acid Res Mol Biol 78: 227-260, 2004

33. Gomes XV and Burgers PMJ: ATP utilization by yeast replication factor C. I. ATP-mediated interaction with DNA and with proliferating cell nuclear antigen. J Biol Chem 276: 34768-34775, 2001. 